\title{
Stories for social change in Hong Kong: an interview with the makers of exodus of nowhere
}

\author{
Anneke Coppoolse*
}

exodus of nowhere is a series of three documentary films that converses its makers', their friends', and family's personal stories about migration with detailed historical narratives about Hong Kong, Mainland China, and the larger Asian region. Lee Wai Yi, Enoch $\mathrm{Ng}$, and Kelvin $\mathrm{Wu}$ - all connected through $v$-artivist, a group of video activists that is concerned with social issues in Hong Kong, specifically with issues surrounding urban redevelopment - have come to the project via their own respective occupations with current matters of belonging and migration. Each of them had become increasingly aware of, and curious about, the meaning of "borders" through their engagements with social movements and this curiosity has resulted in approximately nine hours of film about themselves, the people close to them, and the socio-historical contexts in which they find themselves.

Lee Wai Yi, the most senior member of the group, started participating in social movements as a student in the 1990s. Her first involvement was with protests against the demolition of Hong Kong's rooftop housing - cheap and informal dwellings on top of residential buildings. The social struggle surrounding their survival engaged a progressive and self-organised grassroots movement. From this experience - along a range of other movements related to Hong Kong's grassroots population and their rights to the places in which they lived - she eventually formed, together with friends, v-artivist in 2007. Enoch $\mathrm{Ng}$, then, joined $v$-artivist initially as an intern, years later. As a member of the next generation of students concerned with the society in which they live, he sought answers to questions about the conflicting relation between "local" and "global" in Hong Kong. Kelvin Wu, finally, is another of this new generation of students. Already working with grassroots people in the community-based struggles surrounding urban redevelopment, he joined the project of exodus of nowhere following his concern with anti-migrant sentiments and their exploitation by the government in its claims to the places where, among other people, many migrants live; places that are up for redevelopment towards substantial financial gain.

\footnotetext{
* Lingnan University, Department of Cultural Studies, Tuen Mun, Hong Kong.

With thanks to Lee Wai Yi, Enoch Ng and Kelvin Wu.
} 
Apart from directly addressing the issues they came across via these movements and social struggles, however, the three filmmakers resorted to their own personal backgrounds that directly or indirectly involved stories of migration. They explored their personal lives to better understand and tell about what is going on with borders and migrants - in Hong Kong and in the larger Asian region. Hong Kong as a place that is shaped for a large part by immigrant populations is continuously negotiating who belongs and who doesn't - not only in Hong Kong as a whole, but also in and between its variant neighbourhoods and social groups. Matters of belonging and disbelonging are specifically problematic in light of the territory's socio-economic inequality, where grassroots people normally end up getting the short end of the stick. In the context of these struggles over, essentially, "borders" - being socially, economically, or geographically in or out - through migration, the makers of exodus of nowhere found it important to not simply present an argument against or in favour of certain local policies and public opinions, but to personalise and contextualise what is at stake, subsequently allowing their audiences an opportunity to reconsider their own positions.

In the following interview, I have attempted to grasp the places from which the filmmakers came to produce exodus of nowhere, but also to understand how the narrative form that they have chosen - in the conversation between personal stories and narratives of larger socio-historical contexts - has contributed to their aims to engage certain types of audiences in the spirit of "artivism".

The interview took place at v-artivist's studio in Hong Kong, December 2015.

AC: What is v-artivist? What is your mission?

EN: We have this motto "Returning Art to the People, and Returning the People to Art". So, we try to involve more grassroots people, more powerless people, in art making and art appreciation because we think that art is not just for money and commerce but also for communication. Everybody should have the right and the possibility to communicate with one another.

AC: Do you see art as a tool? A communication tool?

EN: Not exactly. Not just as a tool. It is more like a happening. The whole happening of the activity is art. It's not just something outside of the self, like a tool. We believe that democracy relies on how well people can communicate and make decisions together, equally. So, without a good tradition of communicating with one another, you cannot have democracy. This is basically what 
we spend most of our time trying to work on. We have workshops, videoworkshops, all kinds of screenings. The way we try to do screenings is that we try to link up people through social events; to link up people from different sectors. So that they learn to know each other; so that they have concern for each other. We also have different productions, long and short. We have long productions such as exodus of nowhere, but we also have many short productions such as reports about social events and actions. We are often both the organisers and the ones who document events. Although, we also try for grassroots residents to make recordings themselves. We principally use art as a means by which to organise people. The happening of the organisation of, and communication between, people is what we conceive of as art.

AC: So, from this position, you have come to your project exodus of nowhere? You have made the three episodes with the intention to screen them and make the screenings part of the event of art? Can you elaborate on this? What is exodus of nowhere? And what is the aim of this specific project?

KW: Enoch has a Christian background and so we picked up a biblical reference. "Exodus", in the bible, is the departure from slavery in Egypt, towards the Promised Land. Yet, this journey took a long time and the Promised Land was in the minds of the people first of all an imaginary - a reason to escape, perhaps. I think that "exodus" [in our films] also means escape. Which is understandable, because the place that is escaped from is often oppressive. Unfortunately, though, the place that is escaped to is usually not a promised land, regardless of related dreams about a better life one might find there. This is a struggle for a lot of people. In 99\% of the cases, the promised land doesn't happen. But the imaginary of the promised land is sometimes even used in slogans to attract migrants. For instance, the American Dream. It is indeed a dream, an imaginary. The reality of it is never how it is presented in the dream. In exodus of nowhere, then, we explore migrant stories to reflect certain inbetweenness [between the exodus or escape and the arrival to some form of promised land] and we have picked up on those stories in our own families. There is not yet a dreamland for people. It remains a struggle. There has been an exodus but to nowhere yet.

AC: There are three films - three episodes, the water is wide, gamble, and rondo for the dis/placed - and each of these films involves a number of stories from different people, narrated for a large part by you. How have you defined their common story? Can you explain how you have organised the different narratives that you present in the films towards a common story? 
KW: The theme that seeds through all films is, indeed, "border". Firstly, we narrate how borders are used to exclude people within individual places, but also how they exclude people from entering those places. We explore the political meanings of the shifting of borders. Instead of just presenting borders, we have tried to represent the impact borders have on individuals. We tell stories about how people live through a crossing of borders; stories about people who have been rejected a legitimate identity - citizenship. But we also narrate the actual journeys across borders themselves. Secondly, we try to relate these kinds of stories to Hong Kong society as a whole. We [in Hong Kong] have this idea about our connectivity to the world: a connectivity that involves flows of capital, technology, people, etc. Yet, in reality, there are people coming over to Hong Kong who are being excluded [from both Hong Kong society and the world] and their labour is exploited. I am talking about domestic workers as well as other migrants whose work is exploited.

AC: The stories that you've chosen to represent are for a large part your personal experiences and the experiences of people close to you - family members and close friends. And you have connected these stories to the larger socio-political contexts of Hong Kong, the world. What was your intention to do so?

KW: Yes, my story is about an intimate relationship with a girl whom I met in Mexico. She's from Mainland China. This is actually also one of the reasons why I became interested in the questions of "local" and "migration". Finding a girlfriend across the border made the border between me and her more apparent. Before, I would have said that I know about the issue, but not in a way that directly affected me.

AC: The issue? You mean xenophobia?

KW: Yes, xenophobia [which is an increasing problem in Hong Kong, specifically towards people from the Mainland] but also more practical issues. For instance, I had to start making decisions about where to meet, where to stay, etc. The problem of the border in the relationship with my girlfriend is of course not totally identical to problems other migrants might have. However, I have tried to tell a story about these kinds of decisions that people might have to make when migrating to new places, by telling my personal story: decisions about where to meet next and where to stay. Of course, in the film, there's a "juicy part" [about me meeting my girlfriend] but also a serious part that represents a relationship of young people dealing with problems of borders. Although we are young, university graduates, and therefore more mobile, there are other people in the world and in Hong Kong more specifically, who do not 
have that kind social status or flexibility. Telling my story, I hope, also hints at the potential difficulties others might face when dealing with the same borders.

EN: Generally, in all the three films, we try to represent the individual narratives of a person or a family and also the social narrative of a society, the nation, or historical events. We try to connect these two so that we don't only see ourselves or only see the grand world events that seemingly do not directly affect us or our daily lives. All of us reflect on our own stories and those of our family and friends by making that connection. For me, my family history is quite typical to Hong Kong. You see, many of our grandparents came from Mainland China for various reasons; for political reasons, due to oppression, those kinds of things. They came to Hong Kong in search of a more stable and safer life. That is what also happened to my grandparents. My parents, further, are baby boomers and they grew up as Hong Kong's economy expanded. My parents benefitted from this development and became middle class. This is what happened. But very few people from my generation see themselves as non-Hongkongers. If their grandparents came to Hong Kong in the early days and if their parents are born in Hong Kong, they would consider themselves Hongkongers. But as you can see, we don't have to go back many generations before we get to a migrant. It is odd that we currently have this strong feeling about Hong Kong being "our place" where we have all the rights to claim our resources. More importantly, we are not only claiming and using resources "from Hong Kong". We are actually exploiting resources from elsewhere. In Hong Kong we have domestic workers working for us 24 hours and six days per week, if not seven, at a very low pay. These are people who have had to leave their families back home. Children live without their mothers, because they are caring for other people's children in Hong Kong. Not to mention, also, all the food and water and other basics that we need here in Hong Kong. These things also mainly come from elsewhere. We seldom see it in this way, however. We always think that these are resources that we ought to have and we ought not to share. And it is becoming more problematic now, because today we are no longer the richest society in the region. There are now many people from the Mainland richer than us, which causes us to feel threatened. Our identity is in crisis, as one might call it. And the lesson of this is, perhaps, that we are not always lucky. Situations might change. And this is the underlying message in the part of the film that I narrate.

KW: I would like to add the reason for us to engage in such storytelling. Today, people seem to have lost the ability to tell real stories. One can talk about politics or discourses in very abstract terms, yet this has an alienating effect. Or, one can tell one's own story only to address personal development. 
It seems that, besides abstraction, "development" is all there is to stories. Hong Kong's Urban Renewal Authority, for example, would bring out stories about buildings that are not matching modern requirements and that are subsequently redeveloped and presented in relation to the narratives about Hong Kong's overall development; development that is always celebrated. Indeed, today's stories are either too abstract or they are entirely "a-political". I think that telling personal stories in the way we do in the films, allows a moving away from both abstractions and celebrations of development. The stories that we have tried to capture are told in a language that is understandable. People can relate to the kind of stories we tell. It is like Enoch said, they suggest both the personal journey and the wider context and subsequently hint at the kinds of power relations that allow for such journeying to either fail or succeed. Our films connect the grand narratives to individual stories and allow, in this way, the members of our audience to relate to them and, hopefully, consequently think more about their own situations.

EN: I think that what we learnt [from making these films] is that we are more used to rational or objective ways of narrating things - although it is not necessarily always rational or objective, we pretend it is. But this kind of language does not necessarily connect people. And this is a problem. We, as people with leftist ideas, have lost the ability to connect people through our language [due to the abstraction of our critiques]. Telling individual stories, however, [in the way we did it in the films] helps to again make these connections. It always helps to connect with others, because we have emotions. How we treat our emotions, how we deal with them, is difficult. It should not follow a clear-cut model of difference that suggests that "you are bad" and "I am good" or "somebody is always right" and "somebody else is always wrong". We have to understand situations and relations with other people in order to better understand and deal with our emotions.

AC: Wai Yi, as you trace the stories of your parents in the third episode, rondo for the dis/placed - where they were born and raised and their journeys, as people of Chinese descent, from Malaysia and Indonesia to China and Hong Kong - what current concern did you have that made you want to tell their stories?

LWI: The three of us are not thinking about the older generations nostalgically. We explore their stories for a different purpose. Like I also said in the film, if you do not know what happened before, you cannot understand what is happening now. By featuring what has happened before, we hope that our audience would reconsider whether they still think the same about what 
is happening at the moment. This is a very classic way of telling stories or making films: there are two groups of people that hate each other. One is oppressing the other, but in the end you find out that actually the other guys were the bad ones. There are many such stories. And they are very easy to understand if you know what happened before. Yet, people don't know their history now. For me this is very difficult. When I was in secondary school, students had history lessons - both world history and Chinese history - and although they are all bad histories [badly told], they gave some general context to our situation and we had some understanding of the historical sequence of events. We knew, for instance, that the Second World War [in South-East Asia] was from 1941 till 1945. But nowadays, I don't think people really know anymore when the Second World War was. I think that's very problematic. Further, the Chinese history that was taught followed a very clear authoritarian path. So, if you studied history, you knew politics. In my time, even if you were a bad student, you followed the history lessons in class. You would have picked up some of it. If your history teacher was a good storyteller, then you'd have picked up more and you might have even liked history. The biggest problem now is that we don't have a collective history. We don't know what happened elsewhere. We don't know what happened before. In terms of space and time, we don't know what happened other than what is happening here and now. For me, retracing the histories of my parents, I basically sold out my family to present a story of their history. Or, actually, there were two incentives for the intertwining of personal stories with structural historic descriptions, in my case. I wanted to make an effort towards some kind of family reunion. My father [born in Malaysia] hated my grandfather for a long time because he didn't go to the New Village [a concentration camp that he and his family were asked to move to by the British military during the Malayan Emergency in the 1950s, causing them to be temporarily homeless]. But my father didn't know what this New Village concentration camp was about. [Taking him back to Malaysia to trace his history and showing him this film afterwards, helped him to understand.] For my mum - but also for my dad - I also wanted them to know why I'm doing what I' $m$ doing [engaging in social movements]. After this film, our relationship got much better. This is my personal reason. But the social reason is, indeed, to offer a historical context and more specifically to show that all our personal histories somehow connect to stories of migration to some kind of moving around in search of a [better] life. And, indeed, after each screening we were told other stories by the audience too. I think the films [and the way in which they are constructed] invite more stories. The other thing is that we make use of the "a-political" nature of the individual stories of 
people. That is, we try to approach sensitive issues "a-politically". We don't argue with people. We don't say "now you're wrong", "it should be like this". We just tell stories about people moving across borders due to certain circumstances. We like to achieve the effect of "if it were you, what would you do?"; "what decisions would you make?" It brings people back from the abstract to the human level. That is what we try to do. And during some of the screenings, we might have changed the minds of one or two people with originally more conservative views. Although we might not have instantly changed their minds, we might have helped them to think more. With our film screenings, we are actually targeting three groups of people. One is the group of social workers, because they deal with a lot of new immigrants [many grassroots people are new immigrants from China]. Actually, xenophobia is quite serious among social workers. They think that new immigrants come to benefit from Hong Kong and although it is true that some of them may lie about their situations to get welfare, this is not necessarily true for everyone who comes to Hong Kong. The second group, then, is the church - the Protestant church and Catholic church - because they reach out to many people and they put emphasis on human empathy. So, we would like to try for them to also engage in our discussion on migration.

AC: Do you mean that you would screen the films during certain church gatherings?

LWI: Yes. This is one direction. And the third group is students and people with mildly conservative views, because they are not the far right. They are not yet too xenophobic. They think more rationally. They think "A happened and then B happened", but we can still tell them that actually "after A, B didn't happen but $\mathrm{C}$ happened".

AC: Where would you find these people? Or do you mean you would find them within those different groups - social workers, churchgoers, and students?

EN: Many young people are like this. We'll do screenings in colleges. There are many young people who have good intentions and have concerns about the society but most of their resources are of a more conservative nature, following right-wing discourses and social analyses. So, they would have some xenophobic sentiments but are still open to change. They may not yet have made up their minds. We would like to engage in discussion with them and give them the chance to expose themselves to different ideas. 
AC: Let me share my own experience of watching your films. They are engaging. Even though they are very long, I wanted to keep watching. But I also felt that they overwhelm the audience with information. Many different and very big incidents and historical moments are highlighted - from the Tiananmen Square massacre to the Handover of Hong Kong to China, and from the Japanese invasion of Southeast Asia to the rise of neoliberalism and Thatcherism. It is really an overload of historical facts, personal experiences, dates, events, etc. It all connects with each other, yet it is overwhelming and it therefore requires a lot of labour from your audience as well, to process it all. What I understand from you, though, is that the "event" of the screening is not only about the screening itself but also about the intended discussion afterwards. Which indeed invites members of the audience to share their own stories. So, I think I understand why you have made your films the way you did. You want your audience to put in the labour of processing all they see, to make them think and talk more. This is what I understand from you. exodus of nowhere is, in this way, a never-ending project. But I wonder, since you have produced something like a trilogy, if there is still some kind of closure. Is it going to stop somewhere? Additionally, I wonder - although I know you're still screening it in places, so perhaps you have yet to find out the answer to this last question - whether you think you have succeeded. I wonder whether you think that your approach in telling personal stories in context, has been successful in achieving what you want: engaging discussion, making people think more about their own situations?

EN: As to the potential closure, at the moment we don't have any plans for making a fourth film. But, if we have one, we might make one. We don't know. For now, three films is quite enough for us to do screenings. Because, as we mentioned before, the art is not only the documentaries, it is the event of screening and discussing. We are trying to make an impact through the discussions and so far we have not done this enough. For instance, during the Social Movement Film Festival (2015) there were only two screenings and we have only reached, probably, about 100 people. That's far from enough. We haven't yet reached people in the church either and we have to reach more social workers too. So, this year we're trying to put all our effort in doing screenings and creating discussion. And also in making records of these discussions to continue the discussion.

KW: Yes, it's "unending" in a way. There is a continuation. I think you were asking whether there is an end to the project. The answer to that is very difficult because we hope that by screening the films and creating discussions, people take some of it home and reflect; start to understand the world slightly 
differently. In a place with a population of 7 million people, we have only reached a few. Still, I think we did successfully reach those few. For example, there was a university student who shared with us that after watching the second film she had become more understanding towards her own family. Her stepmother is from China and even though they live together in the same house, she used to have a rather negative feeling towards the person. I'm not saying that she should not feel bothered with her stepmother, but at least by watching our film she came to perceive of her less negatively. She started seeing her family situation in context. This, to me, is already a success. Whether we reach only a hundred or two hundred people that does not matter. As long as we help change some mindsets. This is how I see it.

EN: When it comes to the way in which people tell stories, we - ourselves - are also still learning. The interesting thing is that, last year, some of the audience said that after watching the film [the second episode] they would like to make their own films about their own families. We thought that this was a good thing to hear. Perhaps, at some point, there will be enough audience members to make their own fourth episode. Who knows. We did talk about organising some kind of workshop to help people make their own films.

AC: How about you, Wai Yi? Do you feel satisfied with the kind of responses that you have received?

LWI: There is always room for improvement, of course. I think that we have the potential to do something, but we haven't done it yet. For the time being, we should not be making more films. We should do screenings. The films have to become their own movement, so they need to be screened and discussed and responded to. Rather than putting a lot of time and effort in making another film and do only a few screenings, we want to build on our current films. We don't need to tell any more of our own stories. We can now get more stories from those who see our films. This may not be in the form of a film, but perhaps in the form of real [verbal] storytelling. This is something that we have worked around before. About three years ago we developed a storytelling workshop but it was more suited to people who already wanted to write or tell stories. Perhaps, now, we can do something like that again but engage more people. 